\title{
Protein Malnutrition and Brain Development
}

\section{Mariela Chertoff*}

Laboratorio de Neuroepigenética, Departamento de Química Biológica, Facultad de Ciencias Exactas y Naturales, Universidad de Buenos Aires and CONICET, Ciudad Universitaria Pabellón II - Piso 4- Ciudad Autónoma de Buenos Aires, Argentina

\begin{abstract}
Malnutrition is one of the major factors affecting brain development. In particular, protein malnutrition can result in abnormal development with behavioral consequences. Protein malnutrition reduces brain size, dendritic arborization and cell maturation. In addition, perinatal low protein diet produces changes on neurotransmitters and oxidative status of the brain. As a consequence, failure in normal development produces social and behavioral disabilities that persist during the adult life. The duration and point of onset of dietary restriction is important to comprehend the detrimental effects of low protein diet on brain function. Although during last decades a lot of effort has been done to understand the long lasting effects of perinatal malnutrition, several questions are still unsolved. The present review is focused on neuroanatomical, neurochemical and functional changes observed in rodent models of perinatal malnutrition as well as the future directions of the field.
\end{abstract}

Keywords: Protein malnutrition; Brain development; Glia; Behavior; Neurochemistry

\section{Abbreviations}

AMPA: a-Amino-3-Hydroxy-5-Methyl-4-Isoxazolepropionic acid; Arc: Arcuate Hypothalamic Nucleus; BBB: Blood-Brain Barrier; BDNF: Brain-Derived Neurotrophic Factor; BrdU: Bromo-Deoxy-Uridine; CA: Cornus Ammonis, Region of Hippocampus; CB: Cerebellum; CX: Cortex; DG: Dentate Gyrus; GAD: Glutamic Acid Decarboxylase; GFAP: Glial Fibrillary Acidic Protein; HP: Hippocampus; HT: Hypothalamus; MBP: Myelin Binding Protein; NPY: Neuropeptide Y; P: Postnatal Day; PCNA: Proliferating Cell Nuclear Antigen; PER: Periventricular Hypothalamic Area; FC: Prefrontal Cortex; PVN: Paraventricular Hypothalamic Nucleus; SGZ: Subgranular Zone; VMN: Ventromedial Hypothalamic Nucleus

\section{Introduction}

The United Nations through the FAO report that, at present, 805 million people suffer from some degree of malnutrition, this means almost one in nine of the world population (FAO, 2014 "The State of Food Insecurity in the World"). It is estimated that one third of these people are women of childbearing age. Nutrition is crucial for the maturation and functional development of the central nervous system (CNS). Brain development is a finely controlled process where the cell division, differentiation, migration and connectivity depend on temporally overlapping stages. Any disturbance on this process might affect the brain function. The impact of malnutrition should be analyzed in the context that the brain development differs in term of time of onset and in duration between species and also among different regions on the brain. Epidemiological studies in children exposed to malnutrition show deep changes on behavior [1]. This is because maternal malnutrition alters maturation of brain embryo which results on changes of developmental pattern, modifying the cognitive and socio- emotional functions and producing disturbances in learning and memory. These deficiencies persist in the postnatal period and continue throughout adulthood [2-4], increasing the risk of psychiatric diseases such as depression, personality disorders and schizophrenia [5-6]. It has been shown that malnutrition increases the risk of attention deficits, hyperactivity, aggression and other antisocial behaviors $[7,8]$. This review is focused on rodent models research, which are crucial for deciphering how protein malnutrition affects brain development and modifies their function at several levels. Rodents have been extensively used to understand the process of brain development due to the extremely high similarity on the sequences of steps in this process with human beings. The set up of animal models demonstrates that different structural and functional deficits depend on the type, the onset and the duration of malnutrition. Although the time scale is different, the sequence of key events in brain maturation is largely consistent between humans and rodents $[4,9,10]$. Several strategies are used in order to determine the effect of protein malnutrition on brain. Specific diets containing $30-60 \%$ of necessary protein content are used from 5-6 weeks prior to mating, during gestation/lactation and/or after weaning. In some cases, pups are cross fostered to lactating control dams at birth or followed by periods of rehabilitation with normal chow. This makes possible to establish a time frame for vulnerabilities on specific regions and/or processes associated with neurodevelopmental disorders. During gestation, only amino acids are received by fetus, since proteins do not cross the placenta. Rats exposed to protein malnutrition before mating, during gestation, lactation and/or after weaning display diminished body weight [11]. Santucci et al. find that malnutrition only during lactation shows a similar reduction on body weight, which has a limited recovery after rehabilitation with control chow [12]. These data demonstrate that protein malnutrition produces a general effect on development. The offspring of females malnourished from 5 weeks previous to mating till end of lactation shows the most prominent reduction on weight and brain size, suggesting that when the malnutrition is more severe, the brain size is more affected. In addition to the reduction on body and brain weights, physical growth and neurodevelopment are delayed on male and female pups born to malnourished dams during gestation and lactation [13]. Deficiency

*Corresponding author: Mariela Chertoff, Departamento de Química Biológica, Facultad de Ciencias Exactas y Naturales, Universidad de Buenos Aires, Ciudad Universitaria Pabellón II Piso 4, Ciudad Autónoma de Buenos Aires, C1428EGA Argentina, Tel: 5411 4576-3300/09; E-mail: marielachertoff@gmail.com

Received May 07, 2015; Accepted May 26, 2015; Published June 04, 2015

Citation: Chertoff M (2014) Protein Malnutrition and Brain Development. Brain Disord Ther 4:171. doi:10.4172/2168-975X.1000171

Copyright: @ 2015 Chertoff M. This is an open-access article distributed under the terms of the Creative Commons Attribution License, which permits unrestricted use, distribution, and reproduction in any medium, provided the original author and source are credited. 
on protein ingestion affects all cellular players in brain (Table 1); for this reason a lot of effort has been made on trying to understand how protein malnutrition influences brain function.

\section{Protein Malnutrition and Neuroanatomy}

In rodents, brain development continues after birth, where migration and cellular proliferation takes place. It has been observed that protein deficiency reduces the thickness of the visual cortex, parietal neocortex, dentate gyrus, CA3 and cerebellum [11,14,15]. Moreover, Plagemann et al. determined that the VMN of hypothalamus increased its size while the PVN is reduced after malnutrition, demonstrating that perturbations during development may change the brain organization [16]. Additionally, protein malnutrition changes the number of neurons as well as dendritic arborization complexity and the number of synapses $[11,17]$. Reduced number of neurons in CA1 region of hippocampus has been described after prenatal protein restriction [18]. Interestingly, gender-specific changes were observed on cerebellar development in rats, showing a higher reduction on its size in females compared to males [19], affecting the granular, the molecular and the myelinated layer. The consequence of malnutrition on brain anatomy, through

\begin{tabular}{|c|c|c|c|}
\hline $\begin{array}{l}\text { Animal model, period of LP diet } \\
\text { administration }\end{array}$ & Age of analysis & Observations compared to controls & Reference \\
\hline Mice, from mating to lactation & P1 to adulthood & $\begin{array}{l}\text { Retard physical development } \\
\text { Delay on neurodevelopment } \\
\text { Diminish juvenil play, diminish Motivation and neuromuscular coordination } \\
\text { Increase Anxiety-related and depression-related behavior }\end{array}$ & [13] \\
\hline $\begin{array}{l}\text { Mice, from } 6 \text { weeks before } \\
\text { mating to end of lactation }\end{array}$ & $\begin{array}{l}\text { P7 } \\
\text { P14 } \\
\text { P60 }\end{array}$ & $\begin{array}{l}\text { Reduce total brain weight and BrdU+ cells in } \mathrm{CB} \\
\text { Reduce internal and external granular layer thickness and GFAP+ cells in } \mathrm{CB} \\
\text { Reduce motor coordination }\end{array}$ & {$[14,70]$} \\
\hline Rats, during lactation & $\mathrm{P} 21$ & $\begin{array}{l}\text { Reduce brain weight } \\
\text { Reduce parietal neocortex, paravermal cerebellar CX, DG and CA3 } \\
\text { thickness } \\
\text { Reduce myelination, number and lenght of spines pyramidal cells of lamina } \\
\text { III of the parietal in } \\
\text { neocortex and CA3 region of HP }\end{array}$ & [15] \\
\hline $\begin{array}{l}\text { Rats, from conception to end of } \\
\text { lactation }\end{array}$ & P20 & $\begin{array}{l}\text { Increase VMN volume and reduce PVN volume in } \mathrm{HT} \\
\text { Reduce NPY+ and Galanin+ cells in PVN and Arc } \\
\text { Reduce GFAP+ cells in PER }\end{array}$ & [16] \\
\hline Rats, from E10 to P20 & $\begin{array}{l}\mathrm{P} 20, \mathrm{P} 40 \\
\text { and P70 }\end{array}$ & $\begin{array}{l}\text { Reduced brain size and weight } \\
\text { Reduce cortical arborization }\end{array}$ & {$[17]$} \\
\hline Rat, during gestation & P90 & Reduce number of neurons and volume of CA1 region & [18] \\
\hline $\begin{array}{l}\text { Rats, from mating to end of } \\
\text { lactation }\end{array}$ & $\begin{array}{l}\text { P21 } \\
\text { P93 }\end{array}$ & $\begin{array}{l}\text { Reduce cell proliferation in SGZin juvenils and adults } \\
\text { Diminish performance in novel object recognition } \\
\text { Increase depressive-like behavior }\end{array}$ & [20] \\
\hline $\begin{array}{l}\text { Rats, from } 5 \text { weeks before } \\
\text { mating to birth }\end{array}$ & $\mathrm{P} 7$ and $\mathrm{P} 30$ & Reduced at $\mathrm{P} 7$ but increase at $\mathrm{P} 30 \mathrm{BrDU}+$ cells in $\mathrm{DG}$ and hilus & [21] \\
\hline Rats, from $\mathrm{P} 0$ to $\mathrm{P} 30$ & P180 & Reduce basal dentrites lenght and ramification in cortical layer $\mathrm{V}$ & {$[25]$} \\
\hline $\begin{array}{l}\text { Mice, from } 6 \text { weeks before } \\
\text { mating to end of experiment }\end{array}$ & $\mathrm{P} 30, \mathrm{P} 90$ and $\mathrm{P} 220$ & $\begin{array}{l}\text { Reduce visual cortex volume and thickness Changes on dendrites width and } \\
\text { density and number of synapses depends on cortical layer }\end{array}$ & [26] \\
\hline $\begin{array}{l}\text { Rat, only gestation (pre), only } \\
\text { lactation (post) or both (chron) }\end{array}$ & P30-P90 & $\begin{array}{l}\text { Increase GAD- } 67+\text { interneurones on } \mathrm{DG} \text { at } \mathrm{P} 30 \text { in Pre } \\
\text { and Post but reduce in chron } \\
\text { Reduced GAD- } 67+\text { interneurones on } \mathrm{CA} 1-3 \text { at } \mathrm{P} 30 \text { in post and chron }\end{array}$ & [26] \\
\hline Rats, during gestation & P15, P30, P90 & Reduce alpha1 and beta 2 but increase alpha3 GABA receptor subunits & [27] \\
\hline $\begin{array}{l}\text { Rats, from conception to end of } \\
\text { experiment }\end{array}$ & $\mathrm{P} 21$ and P75 & $\begin{array}{l}\text { Increase Lipoperoxidation in HP and CB } \\
\text { Increase Protein oxidative damage in HP } \\
\text { Increase Superoxide dismutase activity at P75 in HP Reduce Superoxide } \\
\text { dismutase activity at P21 in CB Increase Catalase activity in CX }\end{array}$ & {$[33]$} \\
\hline $\begin{array}{l}\text { Rats, from mating to end of } \\
\text { experiment }\end{array}$ & P60 & $\begin{array}{l}\text { Increase lipid peroxidation in } \mathrm{CX} \text { and } \mathrm{CB} \\
\text { Reduce antioxidant reactivity in } \mathrm{CX} \text { Reduce catalase activity in } \mathrm{CB}\end{array}$ & {$[34,37]$} \\
\hline Rats, first 2 weeks of pregnancy & From E15 to P63 & $\begin{array}{l}\text { Reduce GFAP+ and PCNA cells in CX } \\
\text { Reduce programmed cell death and extracellular matrix }\end{array}$ & [47] \\
\hline $\begin{array}{l}\text { Rats, from birth to lactation } \\
\text { (PM) or till testing (M) }\end{array}$ & P38 & $\begin{array}{l}\text { Reduce dominant and non-social behavior and social } \\
\text { solicitation }\end{array}$ & [68] \\
\hline $\begin{array}{l}\text { Rats, From birth to lactation } \\
\text { (PM) or till adulthood (M) }\end{array}$ & & $\begin{array}{l}\text { Reduced dominant behavior in M Increase social solicitation and non-social } \\
\text { behavior in M and PM }\end{array}$ & [69] \\
\hline Rats, from birth to testing & $\mathrm{P} 7, \mathrm{P} 14$ and $\mathrm{P} 28$ & The longer low protein diet, the lower the anxiolytic- like behavior & [76] \\
\hline $\begin{array}{l}\text { Rats, only gestation, from mating } \\
\text { to end of lactation or only lactation }\end{array}$ & P120-P150 males & Diminish learning and motivation capability & {$[77]$} \\
\hline
\end{tabular}

Table 1: Protein malnutrition effects on brain development. 
changes on brain connectivity, might be the cause of behavioral deficits observed in malnourished people.

It has been shown that cell proliferation is reduced after preand postnatal protein deprivation in cerebellum of P7 mice [14] and subgranular zone of young rats [20]. Prenatal malnutrition produces a decrease of BrdU+ cells in dentate gyrus and hilus at P7 but an increase at P30 [21]. These results suggest that protein deprivation delayed the proliferative waves in hippocampus and cerebellum, regions that are developed mainly postnatally. Changes on the fate of cells as consequence of perinatal protein malnutrition need to be addressed.

\section{Malnutrition and Neuronal Function}

The amino acids are not only part of the proteins, they are also precursors of many neurotransmitters or neurotransmitters themself. Several groups have studied how malnutrition alters the function of neurotransmitter systems [22]. The reduction on protein intake does not always correlates with the effects on neurotransmitters. In the case of glutamatergic system, Fiacco et al.., using a rat model of pre-natal protein malnutrition, observed an increased density of hippocampal kainate receptors, but a normal density of NMDA and AMPA receptors [23]. Additionally, Rotta and colleagues demonstrate that malnutrition during gestation and lactation decreased the vesicular glutamate uptake capacity [24]. These observations suggest that the deficiency of dietary proteins deregulates glutamate signaling through kainate receptors. However, whether the increased availability of glutamate in synaptic cleft might produce excitotoxic damage needs further investigation. Changes on glutamate due to protein malnutrition are accompanied by a reduction on length, number and complexity of dendrites on the cortex and CA3 region [15,25]. Similarly to glutamatergic system, the GABAergic neurons are differentially affected by perinatal protein malnutrition. While GAD-67+ cells are reduced on dentate gyrus of pups born from malnourished dams during gestation and sucking periods, this population increased if the deficient diet is provided only during gestation or lactation [26]. Additionally, when low protein diet is provided only during gestation, the mRNA expression of GABA receptor subunits alpha 1 and beta 2 are reduced and the level of alpha3 subunit is increased [27].

The glutathione system is altered on rat offspring malnourished during the first postnatal week, including the decrease in glutathione content and glutamate uptake. It is also observed the increase in glutamine synthetase expression. Since the astrocytes remove the glutamate from the synaptic cleft, these results reveal specific changes in astrocyte metabolism and, consequently, a higher vulnerability to excitotoxic/oxidative damage [37,38]. Furthermore, the lipid composition of synaptic membranes is subject to developmental regulation and in consequence it is influenced by protein deprivation. Hitzemann observed that long-chain polyunsaturated fatty acids in synaptic membranes in the cortex are modified by malnutrition during sucking period [37]. The changes on lipid composition may affect the axon potential transmission and the release of synaptic vesicles due to changes on plasmatic membrane fluency.

\section{Malnutrition and Glial Function}

Glia, including oligodendrocytes, astrocytes and microglia, are the most abundant cells in the CNS and they are involved in numerous processes in the healthy and diseased brain. In healthy brain, astrocytes are implicated in regulation of potassium levels [39-41], inactivation of neurotransmitters released [42-44], trafficking of metabolites [45] and brain homeostasis [46]. Also, they are responsible for the formation and maintenance of the blood-brain barrier (BBB). As previously described, astrocytes are intimately related to glutamatergic transmission and antioxidant defense. Astrocytes respond to an injury or disease by increasing their number and their volume and by changing the expression of neurotrophins and cytokines. Astrogliosis is observed at birth in response to malnutrition during development in the offspring cortex, hippocampus and cerebellum [47]. However, only extracellular S100B, a marker for mature astrocytes, is increased at P60 [47]. Additionally, Gressens et al. report a reduction on astrogenesis in the cortex of the pups after the consumption of low protein diet during the first two weeks of gestation [48]. Moreover, perinatal malnutrition produces a reduction on GFAP expression on mice cerebellum [14] and rat hypothalamus [16]. These evidences clearly show that the consequence of protein malnutrition on brain is determined by the period and the duration of the malnutrition; compensatory effects are probably produced during dietary rehabilitation. Changes in the astrogenesis might affect the formation of $\mathrm{BBB}$, however the effect of malnutrition on $\mathrm{BBB}$ permeability is unknown.

Oligodendrocytes are responsible for the formation of myelin sheath by wrapping axons allowing rapid and efficient saltatory propagation through the nodes of Ranvier. It has been recently demonstrated that, once myelinated, the long-term integrity of axons depends on glial supply of metabolites and neurotrophic factors. In rodents, oligodendrocyte maturation occurs mainly after birth and it is a process extremely susceptible to stress. Several groups showed that protein malnutrition reduces the quantity and quality of myelin; which changes its composition in offspring brains of the malnourished mums after birth $[49,50]$. More recently, a reduction on MBP expression evoked by malnutrition has been found [51]. Although the consequences of this reduction have not been intensely studied, at least two hypotheses arise. On one case, a failure on insulation and functionality of oligodendrocytes might cause the reduction on neuronal connectivity. On the other hand, the trophic support that the oligodendrocytes exert over axons might be affected; both hypothesis need to be tested.

Microglia is the component of the innate immune system of the CNS and has been intensively studied on inflammatory and neurodegenerative contexts. In response to cell damage, microglia responds quickly changing its morphology, the expression of cytokines, chemokines, surface molecules and their phagocytic activity [5255]. Microglia constantly surveys the parenchyma [56,57], cleans the cell debris or synaptic contacts overproduced during postnatal development and plays an important role in maintaining the homeostasis [58-60]. Microglia expresses also receptors for neurotransmitters and, in consequence, responds to changes in neuronal activity. It has been nicely demonstrated that microglia contact synapses and perform synaptic pruning; aberrant or dysfunctional synaptic buttons are eliminated in response to sensory stimuli or changes in neuronal activity $[61,62]$. Moreover, the neurons are involved in the restoration of the phenotype of "resting" microglia; which promote tissue repair [63]. Several studies report a reduction on synaptic contacts after a period of malnutrition [11]. Recent evidence suggests that dysfunction of microglia in their ability to respond to environmental stimuli during gestation and lactation, through the regulation of epigenetic mechanisms, affects synaptic plasticity [64]. It has been shown that the release of soluble factors by microglia such as BDNF affects basal neurotransmission and synaptic plasticity in the adult brain, as well 
as learning ability [65]. However, whether microglia has a direct role on this phenomenon should be addressed with further experiments. In the case of vitamin $\mathrm{D}$ deficiency, microglia reduces the phagocytic activity and cytokine production [66]. In contrast, thiamine deficiency or homocisteine induce microglia activation [67]. It is known that malnutrition affects the immune system, causing a decrease in defense mechanisms and increased susceptibility to infectious diseases [68]. Though, how the microglia function and their phenotype are affected by protein malnutrition remains to be determined.

\section{Protein Malnutrition and Behavior}

The establishment of appropriate neuronal circuits along with synaptic pruning, neurotransmitters reuptake, homeostatic control and proper myelination determine the brain function of an individual. Juvenile play, occurring before sexual maturation, is very important for the preparation to adult life. Mice born to malnourished dams show a reduction in juvenile play in both sexes even after post weaning rehabilitation [13]. Almeida et al. observed a reduction on the pinning -expression of dominance in a social context- on malnourished rats from birth to P30 but an increase after post weaning rehabilitation [69]. Additionally, wrestling behavior-indicative of social solicitation- is increased in malnourished rats during lactation [70]. No changes are observed if the low protein diet is provided to pups from P30 onwards, evidencing again the effect of adversities during specific windows of vulnerability on brain development.

Malnutrition early in life affects the morphology and neurochemistry of the hippocampus, structure which is known to be involved in learning and memory. However, there are conflicting results on working memory outcomes, with impairments in radial arm maze in mice [71] but not effects in an operant T-maze in rats [72]. In addition, when spatial memory is tested, prenatally malnourished and control rats are similar in their rate of memory acquisition with proximal and distal clues in Morris water maze at weaning and at adulthood [73]. Interestingly, Bronzino and colleagues report that long-term potentiation is difficult to induce and maintain in malnourished rats, which is an indicative of changes on excitability in this region. In adults, reward responses are increased in prenatally malnourished rats [74]. As a correlation between neuro-anatomical changes on cerebellum and brain function, protein malnutrition during development and lactation produces a motor coordination impairment [14] without affecting total motor activity [13]. Moreover, pre- and postnatal malnutrition reduced learning and motivation in an operant task in female and male adult rats [75-77].

Anxiety-like behavior seems to be differentially affected by the time of malnutrition. An increase on anxiety-like behavior is reported in 5 weeks-aged females and males born to malnourished dams during gestation and lactation [13] and in juvenile rats [75,76]. In contrast, postnatal malnutrition reduced the anxiety-like behavior in adult rats. In addition, it is observed an increase on depressive behavior or stress response in mice and rats exposed to protein deprivation during gestation and lactation $[13,20]$. For the mentioned above, behavior of malnourished animals depend on the period of protein deprivation and the duration of the diet, suggesting the existence of particular windows of susceptibility depending on the evaluated task.

\section{Conclusions and Future Directions}

The brain development is highly susceptible to changes in the environment affecting the flow of natural events (Figure 1). The perinatal

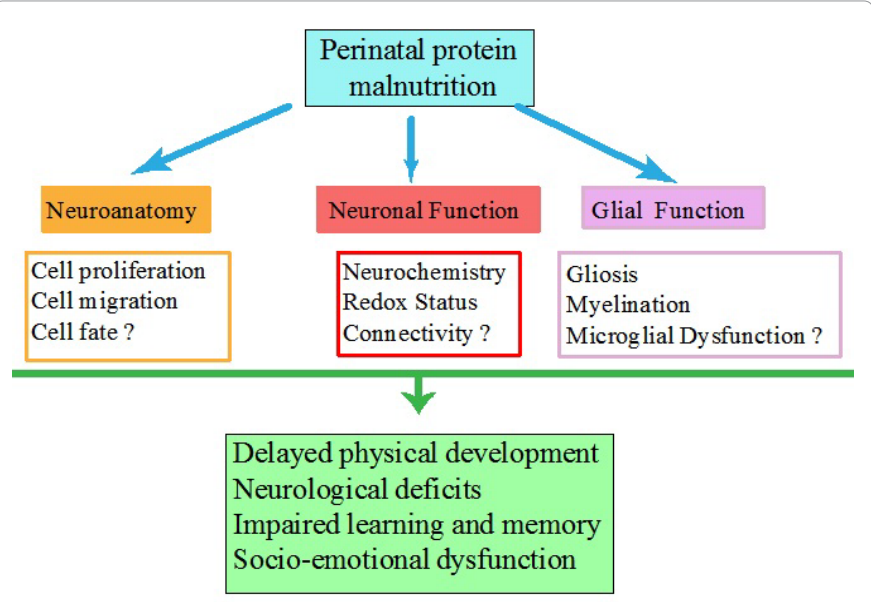

Figure 1: Schematic summary of the effects of perinatal protein malnutrition on brain development. The developmental, behavioral, and cognitive deficits observed on perinatal malnourished animals might derive of their effects on several critical points, including all cell types.

protein malnutrition modifies the neuroanatomy and neurochemistry in several regions. Additionally, low protein diet affects the neuronal communication, which changes the neurotransmitters system. The control of brain homeostasis is also altered by protein deprivation. As a result, developmental disturbance provokes long- term changes on behavior which are not reverted by dietary rehabilitation. Although a lot of studies are focused on molecular changes derived from low protein diet, the mechanisms that produce the persistence of social and behavioral disabilities are not fully understood. There are many issues unsolved which need to be addressed, such as: Does Malnutrition cause a failure in the control of brain homeostasis by glia cells? How is affected neuron-glia communication? What are the changes that occur in each cell type? What are the molecular targets that make changes observed during development lasting till adulthood? Recently, it has been demonstrated that neurons are highly susceptible to change their expression pattern by epigenetic modifications. The study of mechanisms of epigenetic regulation and how these modifications can be reverted after development open a new field of study.

\section{Acknowledgements}

MC would like to thank the Dr Eduardo Cánepa, Dr Silvina Sonzogni and Bruno Berardino for the discussion of this revision. This review was supported by the International Society for Neurochemistry - Committee for Aid and Education in Neurochemistry (CAEN)-Return Home Grant 2013 and the Agencia Nacional de Promoción Científica y Tecnológica (ANPCYT) Grant PICT2011-0196. MC is Research Member of Consejo Nacional de Investigaciones Cientificas y Técnicas (CONICET).

\section{References}

1. Laus MF, Vales LD, Costa TM, Almeida SS (2011) Early postnatal proteincalorie malnutrition and cognition: a review of human and animal studies. Int $\mathrm{J}$ Environ Res Public Health 8: 590-612.

2. Kar BR, Rao SL, Chandramouli BA (2008) Cognitive development in children with chronic protein energy malnutrition. Behav Brain Funct 4: 31.

3. Landon J, Davison M, Krägeloh CU, Thompson NM, Miles JL, et al. (2007) Global undernutrition during gestation influences learning during adult life. Learn Behav 35: 79-86.

4. Morgane PJ, Mokler DJ, Galler JR (2002) Effects of prenatal protein malnutrition on the hippocampal formation. Neurosci Biobehav Rev 26: 471-483.

5. Shen $Q$, Li ZQ, Sun $Y$, Wang T, Wan CL, et al. (2008) The role of proinflammatory factors in mediating the effects on the fetus of prenatal 
undernutrition: implications for schizophrenia. Schizophr Res 99: 48-55.

6. St Clair D, Xu M, Wang P, Yu Y, Fang Y, et al. (2005) Rates of adult schizophrenia following prenatal exposure to the Chinese famine of 1959-1961. JAMA 294: 557-562.

7. Duran P, Cintra L, Galler JR, Tonkiss J (2005) Prenatal protein malnutrition induces a phase shift advance of the spontaneous locomotor rhythm and alters the rest/activity ratio in adult rats. Nutr Neurosci 8: 167-172.

8. Galler JR, Waber D, Harrison R, Ramsey F (2005) Behavioral effects of childhood malnutrition. Am J Psychiatry 162: 1760-1761.162: 1760-1761.

9. Yager JY, Ashwal S (2009) Animal models of perinatal hypoxic-ischemic brain damage. Pediatr Neurol 40: 156-167.

10. Semple BD, Blomgren K, Gimlin K, Ferriero DM, Noble-Haeusslein LJ (2013) Brain development in rodents and humans: Identifying benchmarks of maturation and vulnerability to injury across species. Prog Neurobiol 106-107: 1-16.107: 1-16

11. Díaz-Cintra S, Cintra L, Ortega A, Kemper T, Morgane PJ (1990) Effects of protein deprivation on pyramidal cells of the visual cortex in rats of three age groups. J Comp Neurol 292: 117-126.

12. Santucci LB, Daud MM, Almeida SS, de Oliveira L (1994) Effects of early protein malnutrition and environmental stimulation upon the reactivity to diazepam in two animal models of anxiety. Pharmacol Biochem Behav 49: 393-398.

13. Belluscio LM, Berardino BG, Ferroni NM, Ceruti JM, Cánepa ET (2014) Early protein malnutrition negatively impacts physical growth and neurological reflexes and evokes anxiety and depressive-like behaviors. Physiol Behav 129: $237-254$.

14. Ranade SC, Sarfaraz Nawaz M, Kumar Rambtla P, Rose AJ, Gressens P, et al (2012) Early protein malnutrition disrupts cerebellar development and impairs motor coordination. Br J Nutr 107: 1167-1175

15. Noback CR, Eisenman LM (1981) Some effects of protein-calorie undernutrition on the developing central nervous system of the rat. Anat $\operatorname{Rec} 201: 67-73$.

16. Plagemann A, Harder T, Rake A, Melchior K, Rohde W, et al. (2000) Hypothalamic nuclei are malformed in weanling offspring of low protein malnourished rat dams. J Nutr 130: 2582-2589.

17. Angulo-Colmenares AG, DW. Vaughan, JW Hinds (1979) Rehabilitation following early malnutrition in the rat: body weight, brain size, and cerebral cortex development. Brain Res 169: 121-138.

18. Lister JP, Blatt GJ, DeBassio WA, Kemper TL, Tonkiss J, et al. (2005) Effect of prenatal protein malnutrition on numbers of neurons in the principal cell layers of the adult rat hippocampal formation. Hippocampus 15: 393-403.

19. Hillman DE, Chen S (1981) Vulnerability of cerebellar development in malnutrition-I. Quantitation of layer volume and neuron numbers. Neuroscience 6: 1249-1262.

20. Godoy MA, ouza AS, Lobo MA, Sampaio OV, Moraes L, et al. (2013) Effects of protein restriction during gestation and lactation on cell proliferation in the hippocampus and subventricular zone: functional implications. Protein restriction alters hippocampal/SVZ cell proliferation. Brain Res 1496: 10-27.

21. King RS, DeBassio WA, Kemper TL, Rosene DL, Tonkiss J, et al. (2004) Effects of prenatal protein malnutrition and acute postnatal stress on granule cell genesis in the fascia dentata of neonatal and juvenile rats. Brain Res Dev Brain Res 150: 9-15.

22. Wiggins RC, Fuller G, Enna SJ (1984) Undernutrition and the development of brain neurotransmitter systems. Life Sci 35: 2085-2094.

23. Fiacco TA, Rosene DL, Galler JR, Blatt GJ (2003) Increased density of hippocampal kainate receptors but normal density of NMDA and AMPA receptors in a rat model of prenatal protein malnutrition. J Comp Neurol 456: 350-360.

24. Rotta LN, Leszczinski DN, Brusque AM, Pereira P, Brum LF, et al. (2008) Effects of undernutrition on glutamatergic parameters in the cerebral cortex of young rats. Physiol Behav 94: 580-585.

25. Cordero ME, Trejo M, García E, Barros T, Colombo M (1985) Dendritic development in the neocortex of adult rats subjected to postnatal malnutrition. Early Hum Dev 12: 309-321.

26. Diaz-Cintra S, González-Maciel A, Morales MA, Aguilar A, Cintra L, et al.
(2007) Protein malnutrition differentially alters the number of glutamic acid decarboxylase- 67 interneurons in dentate gyrus and CA1-3 subfields of the dorsal hippocampus. Exp Neurol 208: 47-53.

27. Steiger JL, Alexander MJ, Galler JR, Farb DH, Russek SJ (2003) Effects of prenatal malnutrition on GABAA receptor alpha1, alpha3 and beta2 mRNA levels. Neuroreport 14: 1731-1735.

28. Chen JC, Turiak G, Galler J, Volicer L (1997) Postnatal changes of brain monoamine levels in prenatally malnourished and control rats. Int $\mathrm{J}$ Dev Neurosci 15: 257-263.

29. Mokler DJ, Galler JR, Morgane PJ (2003) Modulation of 5-HT release in the hippocampus of 30-day-old rats exposed in utero to protein malnutrition. Brain Res Dev Brain Res 142: 203-208.

30. Resnick O, Morgane PJ (1984) Ontogeny of the levels of serotonin in various parts of the brain in severely protein malnourished rats. Brain Res 303: 163-170.

31. Soto-Moyano R, Alarcón S, Belmar J, Kusch C, Pérez H, et al. (1998) Prenata protein restriction alters synaptic mechanisms of callosal connections in the rat visual cortex. Int J Dev Neurosci 16: 75-84.

32. Kehoe P, Mallinson K, Bronzino J, McCormick CM (2001) Effects of prenata protein malnutrition and neonatal stress on CNS responsiveness. Brain Res Dev Brain Res 132: 23-31.

33. Bonatto F, Polydoro M, Andrades ME, da Frota Júnior ML, Dal-Pizzol F, et al (2005) Effect of protein malnutrition on redox state of the hippocampus of rat. Brain Res 1042: 17-22.

34. Feoli AM, Siqueira IR, Almeida L, Tramontina AC, Vanzella C, et al. (2006) Effects of protein malnutrition on oxidative status in rat brain. Nutrition 22 160-165.

35. Tatli M, Guzel A, Kizil G, Kavak V, Yavuz M, et al. (2007) Comparison of the effects of maternal protein malnutrition and intrauterine growth restriction on redox state of central nervous system in offspring rats. Brain Res 1156: 21-30

36. Hitzemann R (1981) Developmental changes in the fatty acids of synaptic membrane phospholipids: effect of protein malnutrition. Neurochem Res 6 : 935-947.

37. Feoli AM, Siqueira I, Almeida LM, Tramontina AC, Battu C, et al. (2006) Brain glutathione content and glutamate uptake are reduced in rats exposed to preand postnatal protein malnutrition. J Nutr 136: 2357-2361.

38. Gardner-Medwin AR (1981) Possible roles of vertebrate neuroglia in potassium dynamics, spreading depression and migraine. J Exp Biol 95: 111-127.

39. Gardner-Medwin AR, Coles JA, Tsacopoulos M (1981) Clearance of extracellular potassium: evidence for spatial buffering by glial cells in the retina of the drone. Brain Res 209: 452-457.

40. D'Ambrosio R, Gordon DS, Winn HR (2002) Differential role of KIR channel and $\mathrm{Na}(+) / \mathrm{K}(+)$-pump in the regulation of extracellular $\mathrm{K}(+)$ in rat hippocampus. Neurophysiol 87: 87-102

41. Schousboe A, Hertz L (1981) Role of astroglial cells in glutamate homeostasis Adv Biochem Psychopharmacol 27: 103-113.

42. Drejer J, Meier E, Schousboe A (1983) Novel neuron-related regulatory mechanisms for astrocytic glutamate and GABA high affinity uptake. Neurosc Lett 37: 301-306.

43. Nicholls D, Attwell D (1990) The release and uptake of excitatory amino acids. Trends Pharmacol Sci 11: 462-468.

44. Hertz L, Fillenz M (1999) Does the 'mystery of the extra glucose' during CNS activation reflect glutamate synthesis? Neurochem Int 34: 71-75.

45. Walz W, Mozaffari B (1987) Culture environment and channel-mediated potassium fluxes in astrocytes. Brain Res 412: 405-408.

46. Feoli AM, Leite MC, Tramontina AC, Tramontina F, Posser T, et al. (2008) Developmental changes in content of glial marker proteins in rats exposed to protein malnutrition. Brain Res 1187: 33-41.

47. Gressens P, Muaku SM, Besse L, Nsegbe E, Gallego J, et al. (1997) Maternal protein restriction early in rat pregnancy alters brain development in the progeny. Brain Res Dev Brain Res 103: 21-35.

48. Yusuf HK, Haque Z, Mozaffar Z (1981) Effect of malnutrition and subsequent rehabilitation on the development of mouse brain myelin. J Neurochem 36 924-930.924-30 
49. Egwim PO, Cho BH, Kummerow FA (1986) Effects of postnatal protein undernutrition on myelination in rat brain. Comp Biochem Physiol A Comp Physiol 83: 67-70.

50. Montanha-Rojas EA, Ferreira AA, Tenório F, Barradas PC (2005) Myelin basic protein accumulation is impaired in a model of protein deficiency during development. Nutr Neurosci 8: 49-56.

51. Dalmau I, Finsen B, Zimmer J, González B, Castellano B (1998) Development of microglia in the postnatal rat hippocampus. Hippocampus 8: 458-474.

52. Hanisch UK, Kettenmann H (2007) Microglia: active sensor and versatile effector cells in the normal and pathologic brain. Nat Neurosci 10: 1387-1394.

53. Colton CA (2009) Heterogeneity of microglial activation in the innate immune response in the brain. J Neuroimmune Pharmacol 4: 399-418.

54. Ransohoff RM, Perry VH (2009) Microglial physiology: unique stimuli, specialized responses. Annu Rev Immunol 27: 119-145.

55. Nimmerjahn A, Kirchhoff F, Helmchen F (2005) Resting microglial cells are highly dynamic surveillants of brain parenchyma in vivo. Science 308: 1314-1318.

56. Davalos D, Grutzendler J, Yang G, Kim JV, Zuo Y, et al. (2005) ATP mediates rapid microglial response to local brain injury in vivo. Nat Neurosci 8: 752-758.

57. Tremblay MĖ, Stevens B, Sierra A, Wake H, Bessis A, et al. (2011) The role of microglia in the healthy brain. J Neurosci 31: 16064-16069.

58. Ekdahl CT (2012) Microglial activation - tuning and pruning adult neurogenesis. Front Pharmacol 3: 41.

59. Wake H, Moorhouse AJ, Miyamoto A, Nabekura J (2013) Microglia: actively surveying and shaping neuronal circuit structure and function. Trends Neurosci 36: 209-217.

60. Paolicelli R, Bolasco G, Pagani F, Maggi L, Scianni M, et al. (2011) Synaptic pruning by microglia is necessary for normal brain development. Science 333 1456-1464.

61. Tremblay ME (2011) The role of microglia at synapses in the healthy CNS: novel insights from recent imaging studies. Neuron Glia Biol 7: 67-76.

62. Kettenmann H, Hanisch UK, Noda M, Verkhratsky A (2011) Physiology of microglia. Physiol Rev 91: 461-553.

63. Maezawa I, Calafiore M, Wulff H, Jin LW (2011) Does microglial dysfunction play a role in autism and Rett syndrome? Neuron Glia Biol 7: 85-97.

64. Parkhurst CN, Yang G, Ninan I, Savas JN, Yates JR 3rd, et al. (2013) Microglia promote learning-dependent synapse formation through brain-derived neurotrophic factor. Cell 155: 1596-1609.
65. Djukic M, Onken ML, Schütze S, Redlich S, Götz A, et al. (2014) Vitamin d deficiency reduces the immune response, phagocytosis rate, and intracellular killing rate of microglial cells. Infect Immun 82: 2585-2594

66. Zou CG, Zhao YS, Gao SY, Li SD, Cao XZ, et al. (2010) Homocysteine promotes proliferation and activation of microglia. Neurobiol Aging 31: 2069-2079.

67. Black RE, Allen LH, Bhutta ZA, Caulfield LE, de Onis M, et al. (2008) Maternal and child undernutrition: global and regional exposures and health consequences. Lancet 371: 243-260.

68. Almeida SS, De Araújo M (2001) Postnatal protein malnutrition affects play behavior and other social interactions in juvenile rats. Physiol Behav 74: 45-51.

69. Maria Moreira Camargo L and S de Sousa Almeida (2005) Early postnatal protein malnutrition changes the development of social play in rats. Physiol Behav 85: 246-251.

70. Ranade SC, Rose A, Rao M, Gallego J, Gressens P, et al. (2008) Different types of nutritional deficiencies affect different domains of spatial memory function checked in a radial arm maze. Neuroscience 152: 859-866.

71. Tonkiss J, Galler JR, Formica RN, Shukitt-Hale B, Timm RR (1990) Fetal protein malnutrition impairs acquisition of a DRL task in adult rats. Physio Behav 48: 73-77.

72. Tonkiss J, Shultz P, Galler JR (1994) An analysis of spatial navigation in prenatally protein malnourished rats. Physiol Behav 55: 217-224.

73. Tonkiss J, Shukitt-Hale B, Formica RN, Rocco FJ, Galler JR (1990) Prenatal protein malnutrition alters response to reward in adult rats. Physiol Behav 48: 675-680.

74. Reyes-Castro LA, Rodriguez JS, Charco R, Bautista CJ, Larrea F, et al. (2012) Maternal protein restriction in the rat during pregnancy and/or lactation alters cognitive and anxiety behaviors of female offspring. Int J Dev Neurosci 30: $39-45$.

75. Reyes-Castro LA, Rodriguez JS, Rodríguez-González GL, Chavira R, Bautista CJ, et al. (2012) Pre- and/or postnatal protein restriction developmentally programs affect and risk assessment behaviors in adult male rats. Behav Brain Res 227: 324-329.

76. Françolin-Silva AL, da Silva Hernandes A, Fukuda MT, Valadares CT, Almeida SS (2006) Anxiolytic-like effects of short-term postnatal protein malnutrition in the elevated plus-maze test. Behav Brain Res 173: 310-314.

77. Reyes-Castro LA, Rodriguez JS, Rodríguez-González GL, Wimmer RD, McDonald TJ, et al. (2011) Pre- and/or postnatal protein restriction in rats impairs learning and motivation in male offspring. Int J Dev Neurosci 29: 177-1182. 